\title{
KONTRIBUSI HASIL UJIAN TEORI TERHADAP HASIL UJIAN PRAKTIK PADA UJI KOMPETENSI KEAHLIAN SISWA SMK
}

\author{
Yadi H. Setiana ${ }^{1}$, Syafaruddin Siregar ${ }^{2}$ Haryadi $^{3}$ \\ Departemen Pendidikan Teknik Mesin \\ Universitas Pendidikan Indonesia \\ Jl. Dr. Setiabudhi No. 207 Bandung 40154 \\ yadi_hikmah@yahoo.com
}

\begin{abstract}
ABSTRAK
Tujuan daripada dilakukannya penelitian ini, adalah untuk mengetahui seberapa besar kontribusi hasil uji kompetensi teori kejuruan terhadap hasil uji kompetensi praktik. Metode yang digunakan dalam penelitian ini adalah metode deskriptif korelasional dengan subjek penelitian 124 siswa. Hasil penelitian menunjukkan bahwa tidak terdapat kontribusi antara hasil ujian teori terhadap hasil ujian praktik pada uji kompetensi keahlian (UKK). Selain itu, diperoleh hasil analisis relevansi materi ujian teori kejuruan terhadap hasil ujian praktik kejuruan sebesar $25 \%$ dalam ketegori kurang relevan.
\end{abstract}

Kata kunci: kontribusi, kompetensi,teori kejuruan, praktik kejuruan, relevansi

\section{PENDAHULUAN}

Pada Ujian Kompetensi Keahlian (UKK), masih banyak pesrta didik yang belum mampu melaksanakan ujian teori dan praktik. Tidak terdapat peserta didik yang mendapat nilai ujian teori pada skala 9,0-10 dan haya terdapat dua orang pesertadidik yang mendapat nilai ujian praktik pada skala 9,0-10. Nilai ujian praktik kejuruan sebanyak 2 siswa berada dalam skala 9,0-10, dan 122 siswa berada dalam skala 8,0-8,9,. Pada nilai ujian teori kejuruan terdapat sebanyak 63 siswa dalam skala 8,0-8,9, dan sebanyak 61 siswa dalam skala 7,0-7,9. Hal tersebut terindikasi terjadi penurunan skala antara nilai praktik dengan nilai teori padahal antara teori dan praktik memiliki hubungan yang tidak bisa dipisahkan satu sama lain (Mulyasa, 2011). Teori dan praktik merupakan dua hal yang tidak bisa dipisahkan satu sama lain, harus seimbang dan keduanya mempunyai peran penting, praktik bukan hanya sebagai perwujudan teori belaka, namun menjadi tolak ukur keberhasilan dari teori tersebut Idi, A. (2007).

Hal ini diduga masih belum ada hubungan antara hasil uji praktik dengan hasil uji teori yang seharusnya ada keterkaitan antara keduanya. Materi yang diujikan pada ujian teori terdapat 16 standar kompetensi lulusan yang diujikan untuk peserta didik (Zainal, 2009), yaitu (1) menerapkan perhitungan kekuatan bahan dan komponen mesin dalam pembentukan logam, (2) menjelaskan prinsip dasar kelistrikan dan konversi energi, (3)

\footnotetext{
${ }^{1}$ Mahasiswa Departemen Pendidikan Teknik Mesin FPTK UPI

${ }^{2}$ Dosen Departemen Pendidikan Teknik Mesin FPTK UPI

${ }^{3}$ Dosen Departemen Pendidikan Teknik Mesin FPTK UPI
} 
menjelaskan proses dasar perlakuan logam, (4) Menerapkan keselamatan dan kesehatan kerja (K3) dalam lingkungan kerja, (5) Menggunakan peralatan pembanding dan menggunakan alat ukur dasar, (6) Mengukur dengan alat ukur mekanik presisi, (7) Menerapkan prinsip dasar penggunaan alat-alat perkakas tangan dan perkakas tangan bertenaga, (8) Membaca gambar teknik, (9) Menggunakan mesin untuk oprasi dasar, (10) Melakukan pekerjaan dengan mesin bubut, (11) Melakukan pekerjaan dengan mesin frais, (12) Melakukan pekerjaan dengan mesin gerinda, (13) Menggunakan mesin bubut (kompleks), (14) Menggunakan mesin frais (kompleks), (15) Menggerinda pahat dan alat potong, (16) Menerpkan prinsip dasar pemograman, setting tool dan cara mengoprasikan mesin computer Numerically control (CNC) dasar.

Pada ujian praktik dua standar kompetensi lulusan yang diujikan, yaitu; (1) melakukan pekerjaan dengan mesin bubut dan (2) melakukan pekerjaan dengan mesin frais. Pada kompetensi pekerjaan dengan mesin bubut, kemampuan yang diuji yaitu; (1) memasang benda kerja dan (2) memasang pisau, (3) mengatur putaran mesin, (4) membubut rata, (5) membubut bertingkat, (6) membubut tirus, (7) men-chamfer, (8) mengalur, (9) mengulir, (10) mengebor, dan (11) mengkartel. Pada kompetensi pekerjaan dengan mesin frais, kemampuan yang diujikan yaitu: (1) memasang benda kerja dan (2) memasang pisau, (3) mengatur putaran mesin, (4) memfrais rata, (5) memfrais miring, (6) men-chamfer bidang, (7) mengebor, (8) men-chamfer lubang, dan (9) me-reamer.

Antara materi yang diujikan pada ujian teori masih bayak materi yang tidak diujikan pada ujian praktik, sehingga hubungan antara keduanya diduga masih lemah (Dyah, 2008). Tujuan penelitian ini untuk mencari seberapa besar kontribusi hasil ujian teori terhadap hasil ujian praktikumnya dan relevansi antara materi soal ujian teori terhadap materi soal ujian praktik. Selain itu, untuk mencari data sebaran hasil bilangan pada nilai ujian teori, data sebaran hasil bilangan pada nilai ujian praktik, kontribusi hasil ujian teori terhadap hasil ujian praktik, dan relevansi materi soal ujian teori kejuruan terhadap materi soal ujian praktik kejuruan.

\section{METODE PENELITIAN}

Metode penelitian yang digunakan pada penelitian ini menggunakan metode deskriptif analisis korelasional penelitian yang dirancang untuk menentukan tingkat hubungan variabel-variabel yang berbeda dalam suatu populasi. Pemilihan metode deskriptif korelasional dalam penelitian ini didasarkan dari penelitian yang ingin mengkaji hubungan antar kedua variabel. Pada penelitian ini terdapat dua variabel, yaitu variabel 
independen (variabel bebas) adalah hasil ujian teori kejuruan dan variabel dependen (variabel terikat) adalah hasil ujian praktik kejuruan. Penelitian ini dilaksanakan di SMK Negeri 6 Bandung subjek penelitian yang diambil merupakan siswa tingkat XII tahun 2012/2013 dalam satu angkatan dengan jumlah 124 siswa.

\section{HASIL PENELITIAN}

Hasil uji normalitas yang dilakukan berupa data hasil nilai ujian teori kejuruan dan data hasil nilai ujian praktik kejuruan. Hasil analisis yang dilakukan, diperoleh harga chikuadrat $\left(\chi_{\text {hitung }}^{2}\right)$ untuk data hasil uji teori kejuruan kejuruan sebesar 25,84. Data tersebut kemudian dibandingkan dengan harga Chi-kuadrat tabel $\left(\chi_{\text {tabel }}^{2}\right)$ untuk derajat kebebasan $(\mathrm{dk}=6)$ dengan $\alpha=0,01$ didapat sebesar 16,81 . Dikarenakan harga $\chi^{2}$ hitung nilai ujian teori

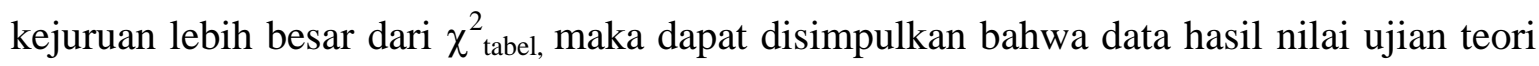
kejuruan berdistribusi tidak normal.

Data hasil uji praktik kejuruan diperoleh harga chi-kuadrat $\left(\chi_{\text {hitung }}^{2}\right)$ sebesar 13,66 dengan derajat kebebasan $(\mathrm{dk}=6)$ menggunakan $\alpha=0,01$ didapat pada Chi-kuadrat tabel

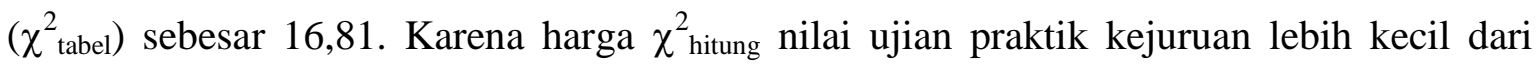
$\chi_{\text {tabel, }}^{2}$ maka hasil nilai ujian praktik kejuruan berdistribusi normal.

Analisis korelasi yang digunakan adalah korelasi Spearman. Hasil pengujian korelasi pada hasil nilai ujian teori kejuruan dan hasil nilai ujian praktik kejuruan diperoleh $r=0,0036$. Diketahui untuk $r=0,0036$ termasuk dalam kategori sangat lemah. Sehingga, dapat disimpulkan bahwa antara hasil nilai ujian teori kejuruan dengan hasil nilai ujian praktik kejuruan bidang kompetensi pemesinan pada kategori sangat lemah atau hampir tidak ada hubungan.

Hasil analisis yang telah dilakukan, diperoleh harga koefisien korelasi (r) sebesar 0,0036, sehingga harga untuk koefisien determinasinya adalah $\mathrm{KD}=(0,003)^{2} \times 100 \%=$ $0,0152 \%$. Kontribusi hasil nilai ujian teori kejuruan terhadap hasil praktik kejuruan sebesar 0,0152\%, sedangkan sisanya 99,98\% dari hasil kontribusi faktor lain diluar hasil nilai ujian teori kejuruan.

Hasil analisis data yang telah dilakukan, diperoleh harga $t$ hitung $\left(t_{\text {hitung }}\right)$ yaitu sebesar 0,043. Harga tersebut selanjutnya dibandingkan dengan harga t tabel $\left(\mathrm{t}_{\text {tabel }}\right)$ untuk $\mathrm{dk}=122$ dengan $\alpha=1 \%$ pada uji dua pihak yaitu sebesar 2,626. Dikarenakan harga $\mathrm{t}_{\text {hitung }}$ lebih besar daripada $t_{\text {tabel }}\left(t_{\text {hitung }}=0,043>t_{\text {tabel }}=2,626\right)$, maka Ho diterima dan Ha ditolak pada taraf kepercayaan $99 \%$. Sehingga dapat disimpulkan bahwa tidak terdapat hubungan 
yang positif dan signifikan antara hasil nilai ujian teori kejuruan terhadap hasil nilai ujian praktik kejuruan bidang kompetensi pemesinan tahun pelajaran 2012/2013.

Hasil analisis yang dilakukan berdasarkan soal ujian teori dan praktik kejuruan pada uji kompetensi keahlian bidang kompetensi pemesinan, diketahui bahwa terdapat 16 materi yang diuji pada ujian teori kejuruan, terdapat 4 materi yang relevan. Sehingga dari data tersebut, diketahui tingkat relevansi materi yang diuji pada ujian teori kejuruan terhadap materi yang diuji pada ujian praktik kejuruan bidang kompetensi pemesinan tahun pelajaran 2012/2013 yaitu sebesar $25 \%$ termasuk dalam kategori kurang relevan.

\section{PEMBAHASAN}

Hasil analisis data tingkat hubungan, koefisien determinasi diperoleh dengan cara mengkuadratkan harga koefisien korelasi dan kemudian dikalikan dengan 100\%. Hasil analisis yang telah dilakukan, diperoleh harga koefisien determinasi sebesar 0,0152\% dan sisanya disumbang oleh faktor lain diluar hasil nilai ujian teori kejuruan (Muslich, 2011). Sehingga dapat disimpulkan bahwa tidak ada kontribusi antara hasil nilai ujian teori kejuruan dengan hasil nilai ujian praktik kejuruan.

Hasil analisis data yang telah dilakukan, diperoleh tingkat relevansi materi soal ujian teori kejuruan terhadap materi soal ujian praktik kejuruan sebesar $25 \%$ dalam kategori kurang relevan, tidak semua materi soal ujian teori ada pada materi soal ujian praktik kejuruan. Tingkat relevansi materi sebesar $25 \%$ atau dalam ketegori kurang relevan, ini salah satu yang menyebabkan kontribusi antara ujian teori terhadap ujian praktik menjadi lemah, ini akan lebih baik jika relevansi materi soal ujian lebih ditingkatkan sehingga dapat meningkatkan hasil uji kompetensi kejuruan siswa Susilana, 2006).

Pendidikan disusun sebagi latar belakang yang hakiki dan sebagai rasional dari praktik dan pada dasarnya bersifat direktif atau memiliki tujuan untuk mencapai kesejahteraan bagi subjek didik, sedangkan praktik adalah tentang pelaksanaan pendidikan secara konkretnya. Teori dan praktik merupakan dua hal yang tidak bisa dipisahkan satu sama lain, harus seimbang dan keduanya mempunyai peran penting, praktik bukan hanya sebagai perwujudan teori belaka, namun menjadi tolak ukur keberhasilan dari teori tersebut (Suderadjat, 2004).

Hasil penelitian menyatakan bahwa tidak terdapat kontribusi yang positif dan signifikan antara hasil ujian teori kejuruan terhadap hasil ujian praktik kejuruan tidak sejalan dengan hasil penelitian yang telah dilakukan dan teori teori yang ada. Implikasi dari 
pembahasan hasil penelitian ini adalah harus ada usaha yang dilakukan untuk peningkatan hubungan antara praktik dan teori, sehingga hubungan antara teori dan praktik menjadi kuat, diantaranya relevansi materi ujian teori dan praktik pada uji kompetensi keahlian pada bidang pemesinan harus ditingkatkan (Shahib, 2005).

\section{KESIMPULAN}

Penelitian ini dapat disimpulkan sebagai berikut: hasil nilai ujian teori kejuruan menunjukan nilai rata-rata sebesar 7,87, hasil nilai ujian praktik kejuruan menunjukan nilai rata-rata sebesar 8,57, hasil nilai ujian teori kejuruan tidak berkontribusi terhadap hasil nilai ujian praktik kejuruan sebesar $0,0152 \%$ atau hampir tidak ada kontribusi. Relevansi materi soal ujian teori kejuruan berada pada kategori kurang relevan terhadap materi soal ujian praktik kejuruan dengan persentase sebesar $25 \%$.

\section{DAFTAR PUSTAKA}

Dyah, R. (2008). Perencanaan Pembelajaran Berbasis Kompetensi. Makalah pada Perencanaan Pengajaran UID, Jakarta.

Idi, A. (2007). Pengembangan Kurikulum Teori dan Praktik.Yogyakarta: Ar-Ruzz Media.

Mulyasa, E. (2011). Kurikulum Tingkat Satuan Pendidikan. Bandung: PT. Remaja Rosdakarya.

Muslich, M. (2011). KTSP Pembelajaran Berbasis Kompetensi dan Kontekstual. Jakarta: Bumi Aksara.

Shahib, N, M. (2005). Pendidikan Berbasis Kompetensi Menuju Invensi. Bandung: Gema Media Pusakatama.

Suderadjat, H. (2004). Implementasi Kurikulum Berbasis Kompetensi (KBK). Bandung: CV. Cipta Cekas Grafika.

Susilana, R. (2006). Kurikulum dan Pembelajaran. Bandung: UPI Press.

Zainal, A. (2009). Evaluasi Pembelajaran. Bandung: PT. Remaja Rosdakarya. 